\title{
Literation movement for leading schools: Best practice and leadership power
}

\author{
Zalik Nuryana', Agus Suroyo ${ }^{2}$, Indah Nurcahyati ${ }^{3}$, Farid Setiawan ${ }^{4}$, Arif Rahman $^{5}$ \\ 1,4,5 Department of Islamic Education, Universitas Ahmad Dahlan, Indonesia \\ ${ }^{2}$ SMP Muhammadiyah Al Mujahidin Gunungkidul, Indonesia \\ ${ }^{3}$ SMA Negeri 1 Cangkringan, Indonesia \\ ${ }^{1}$ School of Education Science, Nanjing Normal University, China
}

\begin{tabular}{l}
\hline \hline Article Info \\
\hline Article history: \\
Received Aug 8, 2019 \\
Revised Jan 8, 2020 \\
Accepted Feb 17, 2020 \\
\hline
\end{tabular}

Keywords:

Islamic schools

Leadership power

Leading schools

Literation movement

Reading culture

\begin{abstract}
The school literacy movement is the first step of scientific development, aimed at enhancing science education. It has an important role in encouraging every citizen to have basic knowledge of the nature of science through active participation. This study aims to analyze the implementation of the School Literacy Movement program designated by the Ministry of Education and Culture due to the poor reading interest Indonesia students from several international surveys. The study was conducted at Al Mujahidin Muhammadiyah Middle School in Yogyakarta, using the qualitative method of data collection. The results show that the school literacy program is not only specific for reading and writing but for also other academics as activities such as numerals, science, digitalization, finance, culture, and citizenship. In conclusion, the implementation of a structured and systematic program positive impacts on the growth of literacy achievement for all school members from students, teachers, down to employees in Indonesia.
\end{abstract}

This is an open access article under the CC BY-SA license.

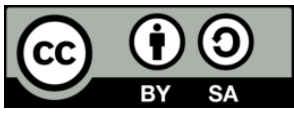

\section{Corresponding Author:}

Zalik Nuryana,

School of Education Science, Nanjing Normal University,

Nanjing, Jiangsu, China.

Department of Islamic Education, Faculty of Islamic Studies, Universitas Ahmad Dahlan,

Ringroad Selatan, Kragilan, Tamanan, Bantul, Daerah Istimewa Yogyakarta 55191, Indonesia.

Email: zalik.nuryana@pai.uad.ac.id

\section{INTRODUCTION}

Currently, the success of a school is not only evaluated by the high results of national examination scores but also the ability to develop students' potential in facing advanced industrial revolution. Therefore, schools need to prepare students to possess the four $\mathrm{C}$ abilities comprising of Critical Thinking and Problem Solving, Creativity, Collaboration, and Communication. Literacy tests measure understanding by reflecting on the reading results obtained in written form. In 2011, Indonesia ranked 45th out of 48 participating countries with a score of 428 from an average score of 500 in the PIRLS International Results in Reading. In 2018 PISA, it ranked 72 with o fits score at 371 from 79 countries. PISA yield comparative indicators of student achievement in various competence domains [1]. Unfortunately, from these data, Indonesian students' competencies, particularly in reading comprehension skills were classified as low [2], which indicates that their literacy level has not developed students' interest in acquiring knowledge. In the PISA survey reading skills, only 30 percent of the total Indonesian student respondents attained level two proficiency. The level of ability to identify the main ideas in medium and long texts. Able to find information based on explicit criteria, although sometimes it is complicated. Also, it can reflect the purpose 
and form of the text when directed to do. Impossible to leading education with bad conditions. This condition driving force the government, and all stakeholders must re-thinking to all the policies that they have made [3].

In the last decade, media literacy education has become a major feature of the school curriculum in most western countries in developing students' skills to understand the media language [4]. By having good reading ability, a student is expected to maximize the skills critically and creatively, following social empathy and knowledge [5]. Furthermore, the curriculum should be appropriately utilized to build character in disaster-prone school areas [6], with literacy movements instilled through games. Alissan and Wendy reported that a pleasant classroom environment would have a positive impact on students' learning [7].

The school literacy movement is the first step of scientific development, aimed at enhancing science education. It has an important role in encouraging every citizen to have basic knowledge of the nature of science through active participation [8]. However, although the school has performed some literacy movement, strengthening its scientific characteristics and HOTS has not been executed by all teachers applying K-13 due to various obstacles [9].

In Al Mujahidin Muhammadiyah Middle School, which is a leading Islamic educational institution, learning should be carried out as a form of worship conducted with sincerity, pure intentions, and positive habit to a generation of the best generation khoiru ummah. For these reasons, every learning activity, including literacy, should be designed to run properly and measurably. However, the two-year literacy movement which began in 2017 has so far succeeded in running properly. Based on the literacy evaluation, there have been positive results for the growth of reading interest at this school. However, it still focuses a lot on reading and writing that other literacy movements, such as a digital, numeral, scientific, financial, cultural, and citizenship needing development. This paper explains the design and implementation of the school literacy movement carried out at Al Mujahidin Muhammadiyah Middle School both nationally and internationally.

\section{RESEARCH METHOD}

The current research was conducted in 2017, Social situation implemented at Al Mujahidin Muhammadiyah Middle School located in Jalan Wonosari-Yogyakarta Km. 05, Logandeng, Plumbon Kidul, Logandeng, Playen, Special Region of Yogyakarta, Indonesia. It was carried out in four stages, namely, program, planning, implementation, and evaluation. The first two were carried out in April 2017/2018, with the evaluation process conducted in several methods, namely reading and writing daily observations, and meetings. Meanwhile, the evaluation is achieved by measuring the processes such as program achievement questionnaires, giving literacy assignments reviewing, composing, etc., or evaluating products. Reports on the implementation of programs are prepared by the literacy team every semester which includes an introduction, program implementation, achievement, costs incurred, production process, constraints faced, and closure, with regular monitoring, carried out by the principal. The data collection techniques used were observation by looking at the implementation of the School Literacy Movement program, in-depth interviews to determine the implementation of programs, and documentation. Sampling in this qualitative study uses nonprobability sampling with a purposive sampling technique that is to obtain data with certain considerations, in this study are the principal and teachers. Furthermore, the data obtained were analyzed using the discovery strategies which involve observer comments, ideas, literature exploration, use of metaphors, and analogies. This research was case study with descriptiv qualitative approach to analyze and explore data using words, phrases, clauses, and sentences. Furthermore, it was thoroughly analyzed to produce a descriptive-analytical study of the literacy movement. The credibility test uses discussion techniques with peers and member checks between researchers.

\section{RESULTS AND DISCUSSION}

Agus Suroyo as the principal in the interview explains, that literacy programs were a concern because they would affect the future of the school. Developing literacy movements means investing in human resources in the future. Some principals acting as coordinators and implementation of the literacy movement in junior high schools have not fully utilized this program due to the numerous inconsistencies attached to its usage. These problems faced are the lack of literacy sources collected in the libraries by principals, teachers, and staff directly involved in the program as well as the students without information on the journals or books to be read [10]. In the end, the teacher is the most influential factor in any program carried out in school. The classroom strategies are constantly adjusted to suit the needs of students, and teachers generally do not follow the recommendations of published verbatim. Theoretical reasons for practice in the classroom 
make this process more explicit, and assuming the teacher knows that something works, they will have the opportunity to modify the technique without disturbing the theoretical foundation [11].

When observing several creative literacy programs were discovered. The Literacy Movement started with a 15-minute reading activity in the morning. In its development, it showed positive effects on the growth of students' reading interest. Table 1 Explain about data on the average number of books and most book readers students. In the release of the Report on Achievement of this school in the framework of the 6th anniversary, the progress of the first semester of the School Literacy Movement for 2018/2019 Academic Year are as follows: First, the average library visit reaches 2,861 students per month, 114 students every day by with 25 effective days per month and $36.10 \%$ of the total number of students. Second, the average book lending per month reaches 363 books. The average number of books students read in 1 semester is presented in Table 1.

Table 1. Data on average number of books and most book readers in $1^{\text {st }}$ semester Al Mujahidin Muhammadiyah Middle School Students academic year of 2018/2019

\begin{tabular}{ccc}
\hline Class & The average number of books read & Most book readers \\
\hline Class 7A & 3 & 8 \\
Class 7B & 3 & 8 \\
Class 7C & 3 & 8 \\
Class 7D & 7 & 12 \\
Class 7E & 6 & 20 \\
Class 8A & 3 & 10 \\
Class 8B & 2 & 10 \\
Class 8C & 5 & 11 \\
Class 8D & 4 & 9 \\
Class 9A & 3 & 11 \\
Class 9B & 6 & 9 \\
Class 9C & 5 & 10 \\
Class 9D & 9 & 30 \\
\hline
\end{tabular}

Mujahidin Magz was featured in digital magazines and has also won 1st place in Contest at DIY Province OLYMPICAD. In terms of supervision, this school also developed the Academic Supervision Application, and a good number of its achievements related to movement include: first, 1st place in the School Magazine competition in the DIY Province OLYMPICAD competition. Second, 1st place at SMP/MTs Library Competition in Gunungkidul. Third, the Winner of Class Action Research Competition on behalf of Muh Erwansyah, M.Psi in 2019 National Olympiad for Talented Teacher and Student Competition. Fourth, the Winner of DIY Province's Ki Hajar Learning Mobile Application Contest on behalf of Hanasto, S.Pd.I, M.S.I and Agus Suroyo, M.Pd.I. Fifth, 3rd place in Class Action Research at Provincial Level Olympicad. Sixth, runner up in the Writing Competition of Middle School Teacher Forum at the Gunungkidul Regency in 2018.

In implementing literacy movement, this school appointed several teachers as program managers, namely, Coordinator of Reading and Writing Literacy by Eka Susila, S.Pd., Coordinator of Science Literacy by Ominia Pratama, S.Pd, Coordinator of Digital Literacy by Hanasto, S.Pd.I, M.S.I, Coordinator of Numeration Literacy by Ari Ernawati, S.Pd., Coordinator of Financial Literacy by Riastuti Puspandari, S.Pd., and Coordinator of Culture and Citizenship Literacy by Aryati Puspitasari, S.Pd.

To support the literacy movement, the school designed several public facilities and corners, such as writing numbers and noble value on the floor stairs, as in Figure 1.

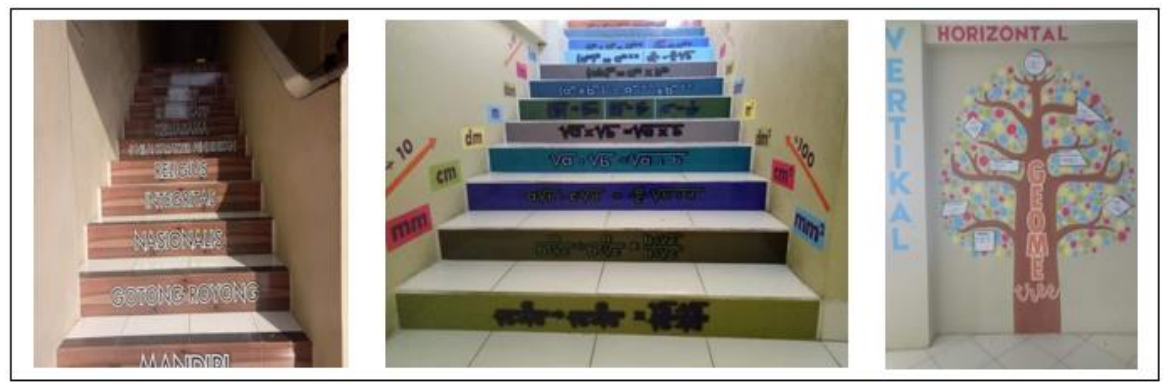

Figure 1. Literacy ladder and painting 


\subsection{A resurgence in interest and motivation}

The school literacy movement impacts on student skills [12], and the most developed aspects were intelligence quotient, emotional, and moral intelligence. It also concluded that in addition to shaping the character and virtuous, reading culture also improved civic intelligence [13, 14]. However, previous research only refers to the implementation of the school literacy movement, without comprehensively including the process from planning, implementation, evaluation, and monitoring. Another positive impact of this program is the increasing involvement of parents with the direct involvement of the community, on literacy cultural awareness, and a book donated for schools from parents and the community [15].

The impact of this program is the increasing public interest in school literacy movement [16]. This activity was carried out 10 minutes before the first-hour lesson and other time variations, such as 30 minutes of reading on Friday [17]. However, several obstacles emerged, including no clear guidance regarding its technical implementation and lack of a comprehensive tool for measuring its success [18]. Therefore, the implementation should be used as a model for national, and international literacy movements.

Table 1, shows that the literacy movement in the School has a positive impact on the growth of students' reading interest. Besides, to support it, the principal also issued special incentives for teachers that wrote classroom action research and books. This also had a positive impact on the production of two classaction studies and three books written by teachers along with the production of six papers in the form of books, namely, “Aku ingin menjadi rembulan” by Dwi Riastuti, M.Pd, Maryam by Immawati Fitri Lestari, M.Pd, "Bukan tutorial jilbab" by Immawatim Fitri Lestari, M.Pd, "Aplikasi supervisi akademik" by Hanasto, MSI, "Media pembelajaran M-Learning Interaktif” by Jaka Prayitna, S.Pd.I, and Couples book for Husband and Wife by Nur Iswanti Hasani, M.Pd. However, these works do not include the research conducted by Agus Suroyo, M.Pd.I and Muh Erwansyah, M.Psi on improving the quality of education in Bantul district which is used as an academic text in making education policy. Furthermore, the classroom action research was conducted by Muhammad Erwansyah, M.Psi and Diyah Fitriasti Khoirunnisa, S.Psi.

The achievements and work of teachers related to literacy indirectly have an impact on the programs carried out in schools. Students visualize these works and achievements which inadvertently builds their motivation to improve literacy skills both inside and outside the school environment which was also supported by the appointment of several teachers as program coordinators. This appointment also uses the theory of knowledge management by the principle to map teacher's knowledge and abilities according to their capacity [19].

\subsection{Development of school literacy movements}

Early literacy development is a continuous develop-mental process that begins in the first years of life [20, 21]. In developing a learning organization, the Ministry of Education and Culture designated the School Literacy Movement. It is a comprehensive effort involving all school members, namely teachers, students, parents/guardians, and the community, as part of the education ecosystem. Table 2 explains the phase of literacy activities and program in schools. Understanding it in this context is the ability to access, and use something intelligently through various activities, including reading, seeing, listening, writing, and/or speaking.

Table 2. Phase of literacy activities and programs in schools

\begin{tabular}{|c|c|c|}
\hline Phase & Activity & Program \\
\hline Habituation 1 & $\begin{array}{l}\text { Growing reading interest through } \\
\text { a } 15 \text {-minute activity (Regulation of } \\
\text { Ministry of Education and Culture } \\
\text { Number } 23 \text { in 2015). }\end{array}$ & $\begin{array}{ll}- & 15 \text { minutes of journal reading } \\
- & \text { Daily reading } \\
- & \text { Structuring literacy facilities } \\
- & \text { Creating a rich text environment } \\
- & \text { Choosing reading books }\end{array}$ \\
\hline Development 2 & $\begin{array}{l}\text { Improve literacy skills through } \\
\text { responding activities to the books. }\end{array}$ & $\begin{array}{ll}\text { - } & 15 \text { minutes of reading } \\
\text { - } & \text { Independent reading hours for curricular / co-curricular } \\
& \text { activities } \\
- & \text { Respond to oral and written readings } \\
- & \text { Non-academic assessment } \\
- & \text { Use of various graphic organizers for reading portfolios } \\
- & \text { Development of physical, social and affective environments }\end{array}$ \\
\hline Learning 3 & $\begin{array}{l}\text { Improve literacy skills in all subjects } \\
\text { using books and reading strategies in all } \\
\text { subjects. }\end{array}$ & $\begin{array}{ll}- & 15 \text { minutes of reading } \\
- & \text { Use of various literacy strategies in cross-disciplinary learning } \\
- & \text { Use of various organizers for understanding and producing } \\
& \text { various types of texts } \\
- & \text { Academic assessment } \\
- & \begin{array}{l}\text { Development of physical, social, affective and academic } \\
\text { environments }\end{array}\end{array}$ \\
\hline
\end{tabular}

Int. J. Eval. \& Res. Educ. Vol. 9, No. 1, March 2020: 227 - 233 
Reference to the school literacy movement in Indonesia. In 2017, only two journals, nine articles, and 12 books spoke about literacy movements, with 60 books sold online in Indonesia [22]. This result encourages efficiency in school literacy movement with the education guarded by all parties. It is also the responsibility of good citizens to develop the younger generation.

Short stories are the best material in teaching [23]. However, schools also use e-literary texts as a material for this program by providing the material needed [24]. On this basis, the school created a program to add 1,000 books to support this literacy movement at Al Mujahidin Muhammadiyah Middle School. This kind of commitment, which is manifested and implemented in a program is what should be carried out and emulated by other schools.

\subsubsection{School literacy movement program}

The principles of literacy include A Reading Readiness Perspective, An Emergent Literacy, A Vygotskian Perspective [25], Oral language development, the beginnings of literacy (Story Reading, Nursery Rhymes, Other Literacy Experiences), and the significance of text [26]. In Indonesia, it is necessary to review the theory as a reference for its development. It also develops a reading theory to maximize the results of this activity [27]. Linda added several stages to maximize the literacy movements in schools, namely, Design Reading Instruction Based on Principles of Motivation and Make Reading Relevant to the Real World [28]. Furthermore, the four key features which appear to be associated with motivation to read are the access to books in the classroom, opportunities to self-select them, familiarity, and the social interactions with others [29]. The literacy program of Al Mujahidin Muhammadiyah Middle School includes: 1). Foundational Literacy, 2). Numerical Literacy, 3). Scientific Literacy, 4). Digital Literacy, 5). Financial Literacy, 6). Cultural and Citizenship Literacy. The role of the school environment is very important in building a literacy culture, including morals [30].

The Foundational literacy is the knowledge and skills to read, write, search, browse, process and understand information as well as to analyze, respond and use written texts to achieve goals, develop understanding and potential, and to participate in the social environment. Table 3 describes the literacy program carried out at Muhammadiyah Al Mujahidin Middle School.

Table 3. Literacy creative programs carried out at Muhammadiyah Al Mujahidin Middle School implemented in schools

\begin{tabular}{|c|c|c|}
\hline No. & Base Development & Program \\
\hline \multirow[t]{3}{*}{1} & Class Base & training for the learning process \\
\hline & & - Integration in a lesson plan \\
\hline & & Reading corners for each class \\
\hline \multirow[t]{10}{*}{2} & School Culture Base & - $\quad$ Availability of 1,000 new book titles in the Library \\
\hline & & - $\quad$ Organizing learning and procurement of Café Read \\
\hline & & - Implementation of Literacy Week activities ahead of national book day \\
\hline & & - $\quad$ Providing PTK Incentives and Book Writers for 10 teachers \\
\hline & & - $\quad$ Establishing a Reading Community at school \\
\hline & & - $\quad$ Procurement of 1,000 new book in the Library \\
\hline & & - $\quad$ Learning Activities in the Library and Café \\
\hline & & - $\quad$ Implementation of Literacy Week activities ahead of national book day \\
\hline & & - $\quad$ Provision of Teacher Incentives and Book Writers \\
\hline & & - $\quad$ Establishment of a Reading Community in schools \\
\hline \multirow[t]{2}{*}{3} & Community Base & $\begin{array}{l}\text { - Submission of CSR/proposal/cooperation in improving literacy facilities } \\
\text { in schools. }\end{array}$ \\
\hline & & Movement of Book Waqf and Literacy Infaq \\
\hline
\end{tabular}

This program is suitable to be implemented in schools, and it was supported by Linda. The role of motivation in the development of literacy culture is as shown in Figure 2.

This program runs well in schools, therefore, students, teachers, employees, and principals should try to implement the movement. Numerical literacy is the knowledge and skill to use various numbers and symbols related to basic mathematics to solve practical problems in daily lives. Numerical literacy help students have been able to understand a problem, to use logic to describe the solution to a problem, and to choose the most appropriate solution to solve a problem [31]. In addition, teacher quality indicators have a positive impact on students' mathematics achievement [32]. It analyzes information displayed in various forms (graphs, tables, charts, etc.), and uses the interpreted results to predict and make decisions. This is also taken from the scope of the 2013 curriculum (K13). Scientific literacy is the knowledge and skills to identify questions, acquire new phenomena that would be used to draw conclusions based on facts, characteristics, awareness, shape of nature, intellectual, and cultural environment as well as the willingness to be involved 
and concerned on science-related issues [33]. There is a significant correlation between scientific literacy and learning achievement [33]. Digital Literacy is the knowledge and skill to use digital media, communication tools, or networks in determining, evaluating, creating information, and utilizing a healthy, wise, intelligent, careful, precise and law-abiding manner to foster communication and interaction in everyday life.

Financial literacy is the knowledge and skills to apply the concept of understanding and risks. It is a skill to make effective decisions in the financial context to improve its well-being, both individually and socially. This is the ability to understand the Indonesian culture as a national identity, while citizenship literacy is the ability to understand the rights and obligations of citizens. Therefore, cultural and citizenship literacy is the ability of individuals and communities to behave towards their social environment as part of a nation. Some countries use the term 6C technique, namely, colonialism, capitalism, conflict, citizenship, and conscientious consumerism to instill cultural and civic literacy [34]. Its implementation is to develop cultural potential.

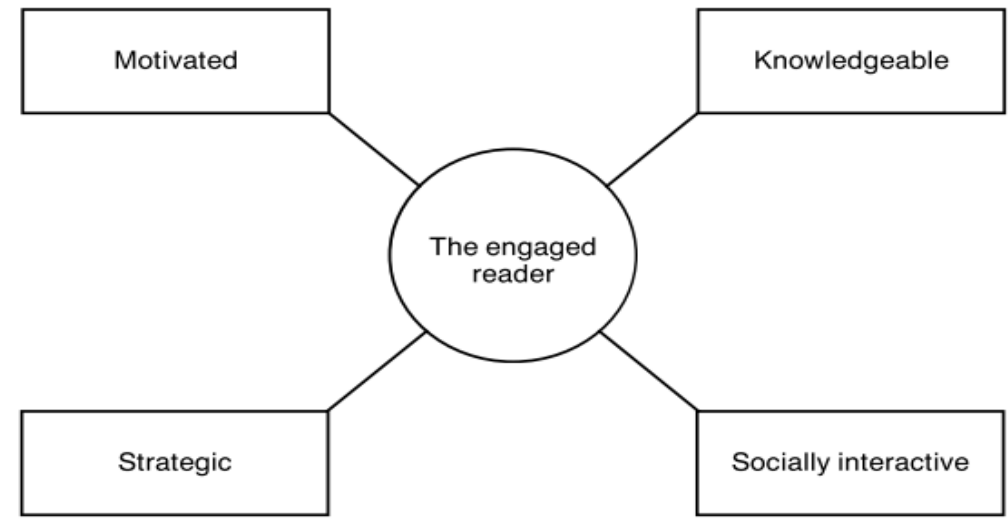

Figure 2. The engaged reader according to Linda B. Gambrell

\section{CONCLUSION}

The school literacy movement held at Al-Mujahidin Muhammadiyah Middle School is used as a model for implementing this program in other schools. It is highly structured with programs ranging from planning, implementation, evaluation, and monitoring. The expertise of principals in organizing human resources needs to be appreciated, therefore, this program, enables schools to cooperate with partners both at home and abroad. The implementation of this program is not only in the reading and writing stage, but in other literacy such as numerical, scientific, digital, financial, and cultural citizenship. With its implementation, the quality of education and its practices in Indonesia tends easily compete with the international world. When the school literacy movement is properly managed, structured, and systematically, it will have a tremendous impact on schools in Indonesia.

\section{ACKNOWLEDGEMENTS}

This research was fully supported by the Department of Islamic Education in Universitas Ahmad Dahlan, Yogyakarta.

\section{REFERENCES}

[1] C. Sälzer and N. Roczen, "Assessing global competence in PISA 2018: Challenges and approaches to capturing a complex construct," Int. J. Dev. Educ. Glob. Learn., vol. 10, no. 1, pp. 5-20, Jun. 2018.

[2] Kemendikbud, Guide to school literacy movements in elementary schools (in Bahasa), 2016.

[3] S. Satrianawati and W. H. Fu, "Education for Sustainable Development (ESD) in Indonesia: A Conceptual Framework," Int. J. Educ. Learn., vol. 1, no. 1, pp. 42-49, Jun. 2019.

[4] E. Babad, E. Peer, and R. Hobbs, "Media literacy and media bias: Are media literacy students less susceptible to nonverbal judgment biases?," Psychol. Pop. Media Cult., vol. 1, no. 2, pp. 97-107, 2012.

[5] F. A. S. Sihaloho, T. Martono, and A. Daerobi, "The Implementation of School Literacy Movement at the Senior High School," Int. J. Educ. Res. Rev., vol. 4, no. 1, pp. 88-96, 2019.

[6] Z. Nuryana and Suyadi, "Development Based on Hidden Curriculum at the Disaster-Prone School," J. Educ. Learn., vol. 13, no. 2, pp. 219-225, 2019. 
[7] A. M. W. Mielonen, "Developing Literacy through Play.," J. Inq. Action Educ., vol. 3, no. 1, pp. 15-46, 2009.

[8] H. Suwono, "School literary movement in Indonesia: Challenges for scientific literacy," Pap. Present. Int. Conf. Educ., pp. 309-317, 2016.

[9] E. Suryawati, F. Suzanti, S. Suwondo, and Y. Yustina, "The implementation of school-literacy-movement: Integrating scientific literacy, characters, and HOTS in science learning," J. Pendidik. Biol. Indones., vol. 4, no. 3, pp. 215-224, 2018.

[10] N. Lastiningsih, T. C. Mutohir, Y. Riyanto, and T. Y. E. Siswono, "Management of the school literacy movement (SLM) programme in indonesian junior secondary schools," World Trans. Eng. Technol. Educ., vol. 15, no. 4, pp. 384-389, 2017.

[11] K. L. Wright, A. D. Franks, L. J. Kuo, E. M. McTigue, and J. Serrano, "Both Theory and Practice: Science Literacy Instruction and Theories of Reading," Int. J. Sci. Math. Educ., vol. 14, no. 7, pp. 1275-1292, 2016.

[12] A. Syawaluddin and N. Nurhaedah, "Effect of school literacy movement (GLS) on students' literacy ability," Int. J. Soc. Sci. Humanit. Res., vol. 6, no. 2, pp. 785-790, 2018.

[13] D. Nurul Aini and Sapriya, "Reading Culture with Medium Gelis Tree (School Literacy Movement) in Develop Students' Civic Intelligence," Int. J. Eng. Technol., vol. 7, no. 3.21, pp. 523-528, 2018.

[14] C. Lahnwong, "The Framework Development for Interpretation of Students Reading Literacy in Teaching and Learning Through Open Approach," in Journal of Physics: Conference Series, 2019.

[15] Z. Slam, "Gerakan Literasi Sekolah Berbasis West Java Leader'S Reading Challange," JMIE (Journal Madrasah Ibtidaiyah Educ., vol. 1, no. 1, pp. 59-79, 2017.

[16] U. Sholahudin, L. M. Dewi, and R. E. Gentari, "Student Empowerment in the Literacy Movement to Increase Interest in Reading School-Age Children [Pemberdayaan Mahasiswa Dalam Gerakan Literasi Untuk Meningkatkan Minat Baca Anak Usia Sekolah]," Proceeding Community Dev., vol. 2, pp. 658, 2019.

[17] E. Erwinsah, M. Solin, and A. Adisaputera, "The Concept of School Literacy Movement Through Reading Time at SDIT Raudaturrahmah Pekanbaru," Budapest Int. Res. Critics Linguist. Educ. J., vol. 2, no. 1, pp. 145-157, 2019.

[18] H. Soepriyanti, "The implementation of School Literature Movement in West Lombok Regency, West Nusa Tenggara Province - Indonesia: an Exploratory Study," in Proceeding of The 1st UR International Conference on Educational Sciences, no. 1, pp. 978-979, 2016.

[19] Z. Nuryana, "Knowledge Management sebagai Upaya Pengembangan Learning Organization di Lembaga Pendidikan Islam," Literasi J. Pendidik., vol. 7, pp. 12-20, 2017.

[20] T. Shanahan, et al., "Developing Early Literacy Skills: A report of the national early literacy panel," 2008.

[21] A. Pellegrini and L. Galda, "Early literacy," in The Development of School-Based Literacy, Routledge, pp. 1-16, 2017.

[22] A. Ahmadi and B. Yulianto, "Descriptive-analytical studies of literacy movement in Indonesia, 2003-2017," Int. J. Humanit. Cult. Stud., vol. 4, no. 3, pp. 16-24, 2017.

[23] A. S. Nova Endriani, Mutsyuhito Solin, "Development of Short Story Text Reading Material Based on Character Education as A School Literacy Movement Material Of Students Class IX SMP Tunas Pelita Binjai," Int. J. Educ. Learn. Dev., vol. 6, no. 12, pp. 71-78, 2018.

[24] D. B. P. Setiyadi, "E-literary Texts: Reading Materials for School Literacy Movement," KnE Soc. Sci., vol. 3, no. 9, pp. 538, 2018.

[25] A. Collins et al., "Center for the Study of Reading," 1987.

[26] B. Hearn, "Literacy and reading development: A review of theories and approaches," Early Child Dev. Care, vol. 86, no. 1, pp. 131-146, 1993.

[27] D. A. R. Costello, "The impact of a school's literacy program on a primary classroom," Can. J. Educ., vol. 35, no. 1, pp. 69-81, 2012.

[28] L. B. Gambrell, "Getting Students Hooked on the Reading Habit," Read. Teach., vol. 69, no. 3, pp. 259-263, 2015.

[29] L. B. Gambrell, "Creating classroom cultures that foster reading motivation," Read. Teach., vol. 50, no. 1, pp. 14-25, 1996

[30] I. Maryani, I. H. Prawestri, D. Sulisworo, S. Urbayatun, S. Suyatno, and C. P. Bhakti, "School environment role towards elementary school students' moral and cultural literacy," J. Educ. Learn., vol. 13, no. 1, p. 33, Feb. 2019.

[31] U. Zainiyah and M. Marsigit, "Improving mathematical literacy of problem solving at the 5th grade of primary students," J. Educ. Learn., vol. 13, no. 1, pp. 98, 2019.

[32] I. Ambussaidi and Y.-F. Yang, "The Impact of Mathematics Teacher Quality on Student Achievement in Oman and Taiwan,” Int. J. Educ. Learn., vol. 1, no. 2, pp. 50-62, Dec. 2019.

[33] J. Jufrida, F. R. Basuki, W. Kurniawan, M. D. Pangestu, and O. Fitaloka, "Scientific literacy and science learning achievement at junior high school," Int. J. Eval. Res. Educ., vol. 8, no. 4, pp. 630-636, 2019.

[34] J. Harshman, "Developing global citizenship through critical media literacy in the social studies," J. Soc. Stud. Res., 2018. 